\title{
Loan Officer and the Evolution of Bank-SMEs Relationship in Tunisia
}

\author{
Fredj Fhima ${ }^{1} \&$ Walid Trabelsi ${ }^{2}$ \\ ${ }^{1}$ Institute of Higher Commercial Studies, University of Sousse, Sousse, Tunisia \\ ${ }^{2}$ Higher Institute of Management, University of Tunis, Tunis, Tunisia \\ Correspondence: Fredj Fhima, Institute of Higher Commercial Studies, University of Sousse, Route Hzamia \\ Sahloul 3 - BP n 40 - 4054 Sousse, Tunisia. Tel: 216-9898-3018. E-mail: ffhima@ yahoo.fr
}

Received: June 14, 2021

Accepted: July 29, 2021

Online Published: August 5, 2021

doi:10.5539/ijef.v13n9p41

URL: https://doi.org/10.5539/ijef.v13n9p41

\begin{abstract}
This paper empirically investigates the role of the loan officer in the evolution of the bank-SMEs relationship and its motivation for studying credit demand, its level of alignment to the hierarchy and its participation in the decision-making process. Based on a survey of 160 loan officers from two large Tunisian commercial banks: the 'Société Tunisienne de Banque' (STB) - as a public bank, and the 'Banque Internationale Arabe de Tunisie' (BIAT) - as a private bank, data analysis shows that self-esteem, need for success, autonomy in performing duties, and participation in the decision-making process are motivating factors at work for loan officers at both banks. The number of visits to the premises of the SME and the average length of interviews with its manager are considered important for the acquisition of soft information. Regarding the decision-making power, while a certain delegation has been instituted at the regional level in the BIAT, it is more the responsibility of the central committees in the STB. The decision of evolution depends more on the hierarchical superiors in a private bank that is why the BIAT officers are closer to their superiors than those of the STB.
\end{abstract}

Keywords: banks, small and medium-sized enterprises, soft information, loan officers, Tunisia

\section{Introduction}

In Tunisia, Small and Medium Enterprises (SMEs) are often exposed to credit rationing because banks consider them as opaque and risky entities (Adair \& Fhima, 2013; Mouley \& Hassen, 2017). By rationing credit to SMEs, Tunisian banks have lost strategic clients, given their importance in the Tunisian enterprises fabric (INS, Business Directory), while they can do otherwise and engage in a long-term relationship for the collection of specific information about these enterprises and the help in credit decision-making (Harhoff \& Körting, 1998; Uzzi \& Lancaster, 2003; Agarwal \& Hauswald, 2010). The bank can offer the enterprise a multitude of services over time (Beck et al., 2018), which it can renegotiate many times in their different dimensions (Roberts, 2015), allowing it to better understand the enterprise's business environment, needs and resources (Ennew \& Binks, 1995). Long-term relationships should thus make it possible to provide better support to the client company and, as a result, ease credit constraints, especially for small enterprises (Beck et al., 2018). According to Berger et al. (2001) and Berger et al. (2005), the ability to maintain a long-term relationship depends on the bank's characteristics, including its size and organizational structure. The presence of several hierarchical levels makes some banks less efficient in processing specific information and leads them to delegate decision-making to their loan officers (Berger \& Udell, 2002); delegation that entails control costs and/or motivational that depends on each bank's characteristics (Jensen \& Meckling, 1992; Stein, 2002).

The purpose of this article is to study the role of the loan officer in the evolution of the relationships between banks and SMEs in Tunisia, his motivation to investigate the credit file, his level of approach to the hierarchy, and his participation in the decision-making process. These subjective elements affect the banking decision (Grunert et al., 2005) but, despite the numerous studies on the banking decision-making process, little research has been done on the role of the loan officer in collecting and analyzing information during the bank-SME relationship (Lehman \& Neuberg, 2001; Lipshitz \& Shulimovitz, 2007). Based on a survey of 160 loan officers across two major Tunisian commercial banks: a public one - the "Société Tunisienne de Banque" (STB) and a private one - the "Banque Internationale Arabe de Tunisie" (BIAT); this paper would like to help fill the research gap on this issue.

The rest of the article is organized as follows: Section 2 begins with a literature review of the importance of 
long-term relationships in acquiring an informational advantage that varies according to characteristics, and shows the role of the loan officer in the collection of specific information and the decision-making to grant credit. According to this review, the hypotheses of our research are formulated. Section 3 presents the questionnaire developed to validate the hypotheses of our theoretical model and describes the various tests carried out to verify the convergent validity, the discriminating validity and reliability of variable part of this study. Section 4 outlines the results of the purification of the measurement scales of the variables and information integrated to our model which allowed us to decide on their value and consistency. The conclusion summarizes our key findings, discusses them and suggests leads for further researches.

\section{Literature and Hypotheses}

\subsection{Literature}

Finance is characterized by an asymmetry of information that plays in favor of the borrower, which will lead the bank to be very careful before engaging in any financing transaction. This caution and doubts often results in some financing difficulties, especially for SMEs whose banks consider their financing to be riskier than the one of large enterprises (Berger et al., 2001; Baas \& Schrooten, 2006). For financing decisions, banks are often forced to reduce credit to SMEs (Levenson \& Willard, 2000; Agostino et al., 2008; Farinha \& Félix, 2015). By doing so, banks although have succeeded in evicting borrowers with higher risks, but they may also have lost strategic customers, given the importance of SMEs in the whole structure of the business market. Banks may however seek to obtain as much information as possible in order to make a better assessment of the specific (idiosyncratic) risk to each category of borrowers. Indeed, in its activity, a bank can acquire two types of information: hard information (quantitative), found externally through public information (rating, score), and soft information (qualitative), through their own customer relationship (Berger \& Udell, 2002; de la Torre et al., 2010; Foliard, 2011). The bank's quality of expertise lies in the long-term relationships that it maintains with its customers and therefore in the specific knowledge and information which come from it. Banks which invested in these customer relationships develop specific procedures to assess the quality of the borrowers (Berger \& Udell, 2006; Cerqueiro et al., 2011; Trönnberg \& Hemlin, 2014). These procedures result in informational benefits, which vary according to the characteristics of the banking institutions, they are mainly: size, structural factors, organization and geographic distance, and the type of ownership.

Regarding the enterprises' size, Petersen (2004), Cole et al. (2004), and Berger and Udell (2003) explain that smaller banks produce more soft information, while larger banks are more interested in hard information. An often empirically proven result is that, as a proportion of their assets, large banks give fewer loans to SMEs than smaller banks (Note 1). According to Berger et al. (2005), small banks have an advantage in terms of processing soft information and ease in establishing a long-term relationship with SMEs. They also make better choices in the selection of granted loans to SMEs (Note 2). Within small banks, management usually belongs to the same socio-economic community as the lender, so the bank is able to better assess a specific situation (Mester et al., 2005) and to exercise its controlling role (Nakamura, 1999).

In terms of organizational factors, small banks have a comparative advantage in estimating projects using soft information. Compared to larger banks, they often have a less complex structure and shorter decision-making processes (with only few hierarchical levels) (Berger \& Udell, 2002; Stein, 2002).

The implementation of the several people involved in the decision-making process, in distinctive areas, increases the problems associated with the transfer of soft information (Hauswald \& Marquez, 2003). Geographic distance generates additional costs and control problems for branch managers located far from the bank's headquarters, making it difficult to remotely monitor the quality of decisions based on soft information (Berger \& DeYoung, 2001). In the presence of a wide geographical distance, it is more likely that the smaller local banks are better to cover the entire local sector through a commercial structure of greater geographical concentration.

Banks working in a given country may be public or private - as they may be local or foreign. According to Berger and Udell (2006), public banks have an advantage in the use of standardized techniques, but they have a disadvantage in the use of long-term relationships. They generally work with government loans and respond to mandates and recommendations provided to support the financing of certain borrowers. Although this policy is intended to improve the financing of SMEs, it could have some perverse effects as public banks can be ineffective as long as they are not subject to market rules and obligations.

Regarding the characteristics of banking institutions, it is difficult for large banks to establish a long-term relationship with enterprises because of the specific nature of the information that does not easily circulate between all the players involved in the credit decision and the different levels of management (Berger \& Udell, 2002; Stein, 2002; Liberti \& Mian, 2009). According to Milgrom and Roberts (1992), the expansion of the size 
of these organizations often results in the problem of weakened coordination, a key element of the decision-making process. Large size is often accompanied by an increase in the number of steps and levels of decision which increases the amount of information transferred to higher levels. Faced to these information flows, they will find themselves unable to make the right decisions.

To deal with this problem, banks often decentralize, which consists of a split of powers between several people; that is a delegation of powers at the lower hierarchical levels in particular to those responsible for clientele (Bruns et al., 2008; Bruns \& Fletcher 2008). Such a measure can be at the origin of agency problems. These responsible provide credit lines and loans to new borrowers to increase the number of clients, instead of checking pre-established relationships. Their reputation is generally based on the credits granted and on the short-term profitability achieved (Udell, 1989). Specifically, they tend to underestimate risk if the relationship is long and if the sector has an "excitement value" (McNamara \& Bromiley, 1997, p. 1079). It is sometimes in the loan officer's interest to hide the financially degraded situation of an enterprise, for reasons of friendship with its manager or for illicit interests that he may acquire. Agency problems can also result from conflicts in the relationship between the agency head and the loan officer (Berger \& Udell, 2002). Through a personalized relationship with his customer, the loan officer can have an informational advantage over other managers involved in the decision-making process. The close relationship between the loan officer and his client may lead him to choose an attitude that is more in the client's interests rather than those of the bank (Udell, 1989; Hertzberg et al., 2010). The difficulty of communicating the information, on which the loan officer relies, makes it difficult to be verified and controlled by his supervisors. In addition, they are more exposed to the lack of information when the power of the loan officer expands with the growth of his number of clients.

The solution to this problem is to increase control by separating the information collection function from the loan and credit allocation. Such a measure often affects the motivations of the loan officer who will no longer be motivated by the collection of specific information, since he no longer has the opportunity to justify it to his supervisors (Stein, 2002). According to Jensen and Meckling (1992), the cost of transferring knowledge increases with the size and structural complexity of the (banking) company. Another option available to the bank is to delegate the decision to grant credit to the loan officers and the agency managers and to set up adequate controls and motivation systems. The Jensen and Meckling's model (1992) is focusing on how the costs of knowledge transfer in an enterprise influence the choice of people with the decision-making rights as well as on the performance measurement and reward systems.

The prediction of Jensen and Meckling (1992) was tested by Nagar (1999) using a database of the structural practices from United States retail banks with respect to agency managers. His work shows the existence of a control system linked to the allocation of the decision-making rights to those responsible. This system measures their performance to determine the level of reward. In a later study, Nagar (2002) empirically verifies the link between the allocation of decision-making rights to agency managers in a retail bank and the reward and motivation systems. Based on a 1994 questionnaires-survey of 135 major United States banks, the study shows that banks that assign more decision-making rights to agency managers are those that use control and measurement systems, as well as more motivating reward methods than those used by other banks.

\subsection{Hypotheses}

The first hypothesis we will test is related to the types of motivation at work. This question is mainly studied by two currents: process theories, which describe the motivational process by "How we are motivated?" (Adams, 1963; Vroom, 1964; Locke, 1968), and content theories, which try to explain "What are we motivated by?" (Maslow, 1954; McClelland, 1961; Herzberg, 1968; Alderfer, 1969). Content can change from one job to another and from a worker to another one; but the process is applicable to all content. It is therefore a matter of identifying the needs of satisfaction in order to improve the employee's performance. According to Maslow (1954), the degree of motivation of a manager, who values the need for self-esteem and self-realization, is measured by the following proposals: an increase in salary or bonus (self-esteem), recognition from the supervisors (self-esteem), the development of professional skills (self-realization), and the search for great consideration by colleagues (self-realization). Being part of everything related to the work and the success of the organization gives an impression of being fully involved in the job, to invest in all the tasks and to up-to-date capabilities. The goal is to achieve the enterprise's objectives which the worker identifies - more or less - with his personal goals. The need for success is activated through working conditions where tasks are intended as indicators of the subject's abilities. Francès (1995) shares the need for success in three factors: the need to do well, competitiveness and the desire to outpace others, and the need to master new tasks.

According to Herzberg (1968), the most important work needs are due to the degree to which individuals attach 
importance to certain attributes of tasks such as variety, autonomy, the use of acquired knowledge, independence of thought, and participation in decision-making. These factors can be motivating factors for workers if they are presented as achievable and non-mandatory improvements.

Our first hypothesis, divided into three, is this one:

H1-a: Forms of motivation to work such as self-esteem, employment involvement, and the need for success encourage the loan officer to increase his commitment to work.

H1-b: Work motivational factors such as the diversity of tasks, autonomy in the performance of his duties, and participation in the decision to grant credit encourage the loan officer to increase his commitment to the job.

H1-c: The loan officer's handling of credit files must depend on his data collection effort.

According to Liberti (2004), the effort and motivation of loan officers in collecting and transferring specific information is affected by the level of delegation of decision-making rights. Banks choosing to provide credit to SMEs must then adopt a decentralized structure that results in the allocation of a significant level of participation to those who hold the specific information (Stein, 2002). At this level, decentralization is not just a matter of determining the decision-maker. While staffs at the lower level of the hierarchy are able to make decisions, when they are pre-planned by the enterprise's structural policy, a high degree of centralization persists. Moreover, decentralization and centralization should not be seen as absolutes, but rather as means of a continuum. Two dimensions are used in the literature: horizontal decentralization and vertical decentralization. Horizontal decentralization shows the dispersion of formal power down within the line of command (Note 3). This delegation of decision-making power can also be done at the lowest level. As for vertical decentralization, it focuses more on the collaboration of enterprise managers in the many decisions of the enterprise (Kalika, 1995). It is the collegial nature of decision-making; this means the number of people involved in decision-making that is apprehended here.

Our second and third hypotheses are the following ones:

H2: The level of loan officer's involvement in decision-making has an influence on the handling of the cases.

H3: The closer the loan officer is to his hierarchy, the more involved he is in the decision-making process.

\section{Data and Tests}

In order to test the plausibility of our hypotheses, we conduct a quantitative study by administering a questionnaire to a sample of loan officers of two Tunisian banks: STB and BIAT (Note 4). This choice is motivated by three main reasons: the first is the size of these banks; in terms of total assets, they are the two largest commercial banks in Tunisia; this allows us to take into account the effect of size and structural complexity. The second is that STB is a public bank and BIAT is a private bank which allows us to see the importance of the ownership of structure on the activity of lending money to SMEs. The third is the loan activity of these two banks; with the National Agricultural Bank, STB and BIAT account for more than $40 \%$ of all loans granted by listed banks (AFC, 2012, p. 8).

\subsection{Elaborating the Questionnaire}

The prepared questionnaire (Appendix 1) brings together questions, elements and variables that help test and validate the assumptions of our model (Note 5). These survey variables can be brought together in three groups. The first relates to variables measuring the efforts made by the loan officer to find information from the director of the SME. The motivation of these managers to seek qualitative information is measured by a first type of skill that is reflected in the maintenance of privileged contacts with the customer. At this point, we are talking about the "Customer Contact" dimension which is dealt with by questions three, four and five. The second group determines the level of motivation of the loan officer in his work. The items proposed in question six help measure the elements of "Motivation by Meeting Needs" or "Motivation to work". Question seven proposes employment attributes proposed by management but not sought by the manager in question. It is based on the principle of diversifying and enriching the tasks (Herzberg, 1968). These attributes can encourage a manager to increase performance if they are proposed as a motivator. The proposed items measure the constructed "Task Attributes" or "Motivational Factors at Work". The third group determines the degree of decentralization of the decision-making power based on two elements, namely vertical decentralization and horizontal decentralization. Question eight verifies the hierarchical level on which the loan officer (vertical decentralization) depends. It corresponds to the element called "hierarchical level". Question nine specifies the collective nature of decision-making (horizontal decentralization). It allows us to measure the "Participation in decision-making" element. Question ten is used to test decentralization in terms of monitoring and controlling the work at the 
agency level. This element is called "Follow and Control".

\subsection{Data Collection and Testing}

The objective of our study is not to compare our theoretical model with several banks, but with several individuals with the same function and belonging to the same hierarchical level, namely the loan officers within the two banks chosen (Note 6).

The data collection began with a qualitative study conducted in the form of semi-directive interviews with 10 loan officers from 10 STB agencies and 10 loan officers from 6 BIAT agencies. This study allowed us to collect a lot of information for the development of a preliminary version of the questionnaire and to test the clarity and level of understanding of the questions asked. These contacts and interviews allowed us to learn about the sources of information used by this manager to decide on a credit application and to identify the practices he is choosing to gain the trust of his customers (interviews carried out, visits to enterprise's premises, etc. (Guille, 1994). The questionnaire was first tested with the loan officers of the agencies where the case studies were conducted and, secondly, with 80 STB loan officers and 80 BIAT loan officers. After the pre-test and due to difficulties in understanding certain proposals by some of the officials, we made some changes to some of the proposals. We conducted a test survey on 15 STB agencies and 20 BIAT agencies located in the Greater Tunis region. The questionnaire was self-administered to each loan officer in our presence in order to see the difficulties encountered by the respondent and explain the main themes of the questionnaire. The objective of the test survey is to assess the level of match of the item measurement scale with the requirements of respondents. The measurement of these elements is then done by using the five-point Likert scale to indicate the level of agreement from the people answering the survey (Cf. Appendix 1). Finally, for the final survey, we used the non-probabilistic method of sampling which involves selecting, through a non-random process, individuals who have experienced significant experiences related to the subject of study and being easily reachable and available (Fortin, 2010).

The geographical space for our study covers: the great Tunis, Mahdia, Monastir, Sousse, Nabeul, Manouba, Bizerte, and Sfax. The administration of our questionnaire, with several loan officers located in different regions and assigned to different agencies - that should respond differently to environmental variables (Hayes, 1977) allows us to explain and compare the evolution of the allocation of decision-making rights in the two banks studied. The questionnaires were given to the loan officers after having carried out an agency interview. The goal being to highlight the reasons and the purpose of the questionnaire while guaranteeing them anonymity. It was a nine months period for our investigation (July 2012 to March 2013).

\section{Results of the Purification of the Measuring Scales of the Elements of the Model}

The elements we are trying to clean up are: Workplace motivation forms, Workplace motivation factors, Data collection skills, Loan officer participation level within the agency and management, and Involvement of the officer in decision-making.

\subsection{Workplace Motivation Forms (H1-A Hypothesis)}

The analysis of this element - including the items in question 6 - reveals that the loan officers of both banks agree $(31.2 \%)$, or even strongly agree $(23.8 \%)$, that a salary or bonus increase is important in terms of self-esteem, and these are the STB officials who are more sensitive to it (30\%) than their BIAT counterparts (25\%) (Table 1), despite generally higher salaries offered in Tunisian public banks (World Bank, 2014, p. 217).

Table 1. Cross table of the self-esteem-1

\begin{tabular}{|c|c|c|c|c|c|}
\hline & & & STB & BIAT & Total \\
\hline \multirow{10}{*}{$\begin{array}{l}\text { Self-esteem-1 } \\
\text { (A salary or bonus } \\
\text { increase) }\end{array}$} & Not at all agree & Size & 14 & 8 & 22 \\
\hline & & $\%$ of total $^{\mathrm{a}}$ & 8.8 & 5.0 & 13,8 \\
\hline & Disagree & Size & 10 & 9 & 19 \\
\hline & & $\%$ of total $^{\mathrm{a}}$ & 6.2 & 5.6 & 11.9 \\
\hline & Neither disagree nor agree & Size & 8 & 23 & 31 \\
\hline & & $\%$ of total $^{\mathrm{a}}$ & 5.0 & 14.4 & 19.4 \\
\hline & Agree & Size & 23 & 27 & 50 \\
\hline & & $\%$ of total ${ }^{a}$ & 14.4 & 16.9 & 31.2 \\
\hline & Absolutely agree & Size & 25 & 13 & 38 \\
\hline & & $\%$ of total $^{\mathrm{a}}$ & 15.6 & 8.1 & 23.8 \\
\hline \multirow{2}{*}{\multicolumn{2}{|c|}{ Total }} & Size & 80 & 80 & 160 \\
\hline & & $\%$ of total $^{\mathrm{a}}$ & 50.0 & 50.0 & 100.0 \\
\hline
\end{tabular}

a. The reasoning is by column, dividing the size in question by the total of the loan officers of the two banks, for example: $8.8 \%=14 / 160$. 
The increased recognition on the part of the supervisor is not significantly different between the two institutions (chi-square $=0.075$; Appendix 2A). In line with Maslow's theoretical predictions (1958), loan officers at both banks consider this to be important in terms of self-esteem. It motivates them indirectly and allows them to expect a reward and an evolution in the future (Table 2).

Table 2. Cross table of the self-esteem -2

\begin{tabular}{|c|c|c|c|c|c|}
\hline & & & STB & BIAT & Total \\
\hline \multirow{10}{*}{$\begin{array}{l}\text { Self-esteem-2 } \\
\text { (Increased recognition } \\
\text { from your supervisor) }\end{array}$} & \multirow[t]{2}{*}{ Not at all agree } & Size & 14 & 9 & 23 \\
\hline & & $\%$ of total ${ }^{\mathrm{a}}$ & 8.8 & 5.6 & 14.4 \\
\hline & \multirow[t]{2}{*}{ Disagree } & Size & 10 & 9 & 19 \\
\hline & & $\%$ of total ${ }^{a}$ & 6.2 & 5.7 & 11.9 \\
\hline & \multirow[t]{2}{*}{ Neither disagree nor agree } & Size & 8 & 21 & 29 \\
\hline & & $\%$ of total $^{\mathrm{a}}$ & 5.0 & 13.1 & 18.1 \\
\hline & \multirow[t]{2}{*}{ Agree } & Size & 23 & 24 & 47 \\
\hline & & $\%$ of total $^{\mathrm{a}}$ & 14.4 & 15 & 29.4 \\
\hline & \multirow[t]{2}{*}{ Absolutely agree } & Size & 25 & 17 & 42 \\
\hline & & $\%$ of total $^{\mathrm{a}}$ & 15.6 & 10.6 & 26.2 \\
\hline \multirow[t]{2}{*}{ Total } & & Size & 80 & 80 & 160 \\
\hline & & $\%$ of total ${ }^{\mathrm{a}}$ & 50.0 & 50.0 & 100.0 \\
\hline
\end{tabular}

a. The reasoning is by column, for example: $8.8 \%=14 / 160$.

BIAT officials seek the consideration of their colleagues who can influence the line managers and their evolution in a private bank. The chi-square test is significant (chi-square $=0.034$; Appendix 2B) which means that STB officials are not too concerned about this consideration, which has only a "Prestige" effect in a state bank where evolution is structured and follows standards and laws provided for by the labor code (Table 3). This translates into lower performance pressure in the workplace. In this sense, the self-realization of the "Professional skills development" item is clearly different from the importance given; it is higher on the BIAT side; the test being significant (chi-square $=0.045$; Appendix 2C). These results confirm the difference between working in a private bank and working in a state-owned bank (Table 4), and may explain the weaker performance of Tunisian public banks than those of other banks (World Bank, 2014, p. 222).

Table 3. Cross table of the self-realization- $1^{\text {a }}$

\begin{tabular}{llllll}
\hline & & & STB & BIAT & Total \\
\hline $\begin{array}{l}\text { Self-realization-1 } \\
\text { greater consideration by your }\end{array}$ & \multirow{2}{*}{$\begin{array}{l}\text { Neither disagree nor agree } \\
\text { colleagues) }\end{array}$} & Size & 0 & 4 & 4 \\
& \multirow{2}{*}{ Agree } & \% of total ${ }^{\text {a }}$ & 0.0 & 2.5 & 2.5 \\
& & Size & 32 & 21 & 53 \\
& & \% of total ${ }^{\text {a }}$ & 20.0 & 13.1 & 33.1 \\
& & Size & 48 & 55 & 103 \\
\hline Total & & \% of total ${ }^{\text {a }}$ & 30.0 & 34.4 & 64.4 \\
& & Size & 80 & 80 & 160 \\
\hline
\end{tabular}

a. Unlike the table for question 6, here the scale contains three choices instead of five because the respondents chose only these three answers.

b. The reasoning is by column, for example: $20 \%=32 / 160$.

Table 4. Cross table of the self-realization -2

\begin{tabular}{llllll}
\hline & & & STB & BIAT & Total \\
\hline Self-realization -2 (Professional & Agree & Size & 33 & 21 & 54 \\
skills development) & & \% of total ${ }^{\text {a }}$ & 20.6 & 13.1 & 33.7 \\
& Absolutely agree & Size & 47 & 59 & 106 \\
& & \% of total ${ }^{\text {a }}$ & 29.4 & 36.9 & 66.3 \\
\hline Total & & Size & 80 & 80 & 160 \\
& & \% of total ${ }^{\text {b }}$ & 50.0 & 50.0 & 100.0 \\
\hline
\end{tabular}

a. The reasoning is by column, for example: $8.8 \%=14 / 160$. 
The two items relating to participation or involvement in employment $\left(5^{\text {th }}\right.$ and $6^{\text {th }}$ items in question 6$)$ do not depend on the status of the bank; the managers of both banks want to apply their own methods and the development of their own action plans. At this level, the manager is well involved and well-motivated (Table 5 and Table 6).

Table 5. Cross table of the participation-1

\begin{tabular}{|c|c|c|c|c|c|}
\hline & & & STB & BIAT & Total \\
\hline \multirow{8}{*}{$\begin{array}{l}\text { Participation-1 (Applying your } \\
\text { methods, your personal work } \\
\text { practices) }\end{array}$} & \multirow[t]{2}{*}{ Disagree } & Size & 1 & 2 & 3 \\
\hline & & $\%$ of total ${ }^{a}$ & 0.6 & 1.2 & 1.9 \\
\hline & \multirow[t]{2}{*}{ Neither disagree nor agree } & Size & 10 & 13 & 23 \\
\hline & & $\%$ of total ${ }^{\mathrm{a}}$ & 6.2 & 8.1 & 14.4 \\
\hline & \multirow[t]{2}{*}{ Agree } & Size & 31 & 36 & 67 \\
\hline & & $\%$ of total ${ }^{a}$ & 19.4 & 22.5 & 41.9 \\
\hline & \multirow[t]{2}{*}{ Absolutely agree } & Size & 38 & 29 & 67 \\
\hline & & $\%$ of total $^{\mathrm{a}}$ & 23.8 & 18.1 & 41.9 \\
\hline \multirow{2}{*}{\multicolumn{2}{|c|}{ Total }} & Size & 80 & 80 & 160 \\
\hline & & $\%$ of total ${ }^{\mathrm{a}}$ & 50.0 & 50.0 & 100.0 \\
\hline
\end{tabular}

a. The reasoning is by column, for example: $0.6 \%=1 / 160$.

Table 6. Cross table of the participation -2

\begin{tabular}{|c|c|c|c|c|c|}
\hline & & & STB & BIAT & Total \\
\hline \multirow{8}{*}{$\begin{array}{l}\text { Participation-2 (Developing an } \\
\text { action plan and/or strategy } \\
\text { defined by the agency (or bank) } \\
\text { to process credit cases) }\end{array}$} & \multirow[t]{2}{*}{ Disagree } & Size & 1 & 1 & 2 \\
\hline & & $\%$ of total ${ }^{a}$ & 0.6 & 0.6 & 1.2 \\
\hline & \multirow[t]{2}{*}{ Neither disagree nor agree } & Size & 9 & 12 & 21 \\
\hline & & $\%$ of total ${ }^{\mathrm{a}}$ & 5.6 & 7.5 & 13.1 \\
\hline & \multirow[t]{2}{*}{ Agree } & Size & 31 & 36 & 67 \\
\hline & & $\%$ of total ${ }^{\mathrm{a}}$ & 19.4 & 22.5 & 41.9 \\
\hline & \multirow[t]{2}{*}{ Absolutely agree } & Size & 39 & 31 & 70 \\
\hline & & $\%$ of total ${ }^{\mathrm{a}}$ & 24.4 & 19.4 & 43.8 \\
\hline \multirow{2}{*}{\multicolumn{2}{|c|}{ Total }} & Size & 80 & 80 & 160 \\
\hline & & $\%$ of total ${ }^{\mathrm{a}}$ & 50.0 & 50.0 & 100.0 \\
\hline
\end{tabular}

a. The reasoning is by column, for example: $0.6 \%=1 / 160$.

Regarding the commitment to the enterprise, the test is non-significant (chi-square $=0.713$; Appendix 2D). This means that the managers of both banks are fully committed to achieving the objectives of their agencies.

The need for success - as presented by the last three items of question 6 (Acquiring new skills, Wanting to get ahead of other loan officers, and Adapting work to every situation encountered) - is a goal for managers of both banks. They are always looking, through training, to learn new ways of working to get ahead of others (Table 7).

Table 7. Distribution of the need for success in percentage

\begin{tabular}{lllllll}
\hline & \multicolumn{2}{l}{ Need for success -1} & \multicolumn{2}{l}{ Need for success -2} & \multicolumn{2}{l}{ Need for success -3} \\
\hline & STB & BIAT & STB & BIAT & STB & BIAT \\
\hline Not at all agree & 0.0 & 0.0 & 0.0 & 0.0 & 0.0 & 0.0 \\
Disagree & 0.0 & 0.0 & 0.0 & 0.0 & 0.0 & 0.0 \\
Neither disagree nor agree & 0.0 & 0.0 & 0.0 & 0.6 & 0.0 & 0.6 \\
Agree & 21.9 & 15.6 & 21.9 & 17.5 & 21.9 & 17.5 \\
Absolutely agree & 28.1 & 34.4 & 28.1 & 31.9 & 28.1 & 31.9 \\
\hline
\end{tabular}

A review of the percentages of responses to items in this element (Table 8) shows that respondents are seeking to meet the need for success, a participation and involvement in employment. 
Table 8. Purification of the construct "Motivation to work" (question 6)

\begin{tabular}{|c|c|c|c|c|c|c|}
\hline \multirow{2}{*}{$\begin{array}{l}\text { Label of the } \\
\text { item } i\end{array}$} & \multirow[t]{2}{*}{ Correlation } & \multirow{2}{*}{$\begin{array}{c}\text { Cronbach's alpha } \\
\text { when the item is } \\
\text { deleted }\end{array}$} & \multirow[t]{2}{*}{ Extraction } & \multicolumn{3}{|c|}{ Percentage of variance explained: 80.457} \\
\hline & & & & $\begin{array}{l}\text { Axis 1: } \\
42.925 \\
\end{array}$ & $\begin{array}{l}\text { Axis } 2 \text { : } \\
21.643 \\
\end{array}$ & $\begin{array}{l}\text { Axis 3: } \\
15.889 \\
\end{array}$ \\
\hline Self esteem-1 & 0.448 & & & & & \\
\hline Self esteem -2 & 0.446 & & & & & \\
\hline Self realization-1 & 0.632 & 0.744 & 0.855 & & & 0.659 \\
\hline Self realization -2 & 0.676 & 0.732 & 0.864 & & & 0.621 \\
\hline Participation-1 & 0.578 & 0.738 & 0.911 & & 0.693 & \\
\hline Participation-2 & 0.573 & 0.739 & 0.917 & & 0.729 & \\
\hline Commitment to work & 0.725 & 0.797 & 0.129 & & & 0.253 \\
\hline Need for succes -1 & 0.629 & 0.713 & 0.961 & 0.879 & & \\
\hline Need for succes -2 & 0.648 & 0.721 & 0.901 & 0.835 & & \\
\hline Need for succes -3 & 0.805 & 0.721 & 0.899 & 0.839 & & \\
\hline $\mathrm{KMO}=0.681$ & \multicolumn{3}{|c|}{ Global Cronbach's alpha $=0.764$} & Need for succes & Participation & Self realization \\
\hline
\end{tabular}

The results summarized in the table above confirm the three-dimensionality of the "Motivation to work" construct, which affirms the advances of theory in this field (Francès, 1995; Herzberg, 1968). The KMO index is significant (0.681). The coefficients of the anti-image matrix are greater than 0.5 , except for items 1 and 2 , that will be eliminated from the analysis (Note 7). The percentage of variance explained is in the order of $81 \%$; it is broken down as follows: the first factor recovers about $43 \%$ of the total variance, the second recovers almost $22 \%$, and the rest is recovered by the third factor. The scale is well reliable, Cronbach's alpha is 0.764. The F1 factor includes the three items that measure the need for success: Acquiring new skills, Wanting to outpace others, and Adapting work to each situation encountered. The F1 axis is called "Need for Success". The F2 factor includes the two items measuring participation or involvement in employment, namely: Application of personal working methods and practices, and Development of an action plan or strategy defined by the agency. The F2 axis is called "Participation". The F3 factor includes the two items that measure self-realization, namely: Salary or bonus increase, and Increased recognition by the supervisor. The F3 axis is called "Self-Realization". These results, grouped into an element called "Behavioral factors", show that the first hypothesis relating to forms of work motivation is mainly verified in Tunisia in privately banks.

\subsection{Motivational Factors at Work (Hypothesis H1-b)}

The analysis of this element - including the five items in question 7 - shows that, regardless of the bank, the loan officers consider it is important and that they are in complete agreement. Within Tunisian banks, the diversity of tasks, autonomy in the exercise of their activity, decision-making initiative, the use of knowledge, and participation in decision-making are motivating factors at work; the chi-square test is insignificant (Appendix 2E). A review of the percentages of responses to these latter items (Table 9) shows that loan officers are looking for a participatory structure. These results confirm the one-dimensionality of the "Structural Motivation at Work" element.

Table 9. Purification of the construct "motivating factors at work" (question 7)

\begin{tabular}{|c|c|c|c|c|}
\hline \multirow[t]{2}{*}{ Label of the item i } & \multirow[t]{2}{*}{ Correlation } & \multirow{2}{*}{$\begin{array}{c}\text { Cronbach's alpha when } \\
\text { the item is deleted }\end{array}$} & \multirow[t]{2}{*}{ Extraction } & Percentage of variance explained: 69.694 \\
\hline & & & & Axis 1: 69.694 \\
\hline Diversity of tasks & 0.905 & 0.875 & 0.632 & 0.795 \\
\hline Autonomy in the performance of duties & 0.868 & 0.856 & 0.723 & 0.850 \\
\hline Initiative in the decision-making & 0.819 & 0.842 & 0.785 & 0.886 \\
\hline $\begin{array}{l}\text { Use of the knowledge gained from the } \\
\text { processing of cases }\end{array}$ & 0.853 & 0.855 & 0.717 & 0.847 \\
\hline Participation in the grant credit decision & 0.900 & 0.875 & 0.628 & 0.792 \\
\hline $\mathrm{KMO}=0.865$ & Glo & bal Cronbach's alpha $=0$ & 886 & Organizational \\
\hline
\end{tabular}

In the table above, the KMO index is significant $(0.865)$ and the coefficients of the anti-image matrix are greater than 0.5 . The percentage of variance is in the $70 \%$ for a single factor. The scale is well reliable; the Cronbach's alpha is 0.886 . The F1 factor includes the last five items measuring the organizational motivator. The F1 axis is called "Organizational". Hypothesis $H 1-b$ relating to work motivation factors is verified. 


\subsection{Data Collection Skills (Hypothesis H1-C)}

Regarding the item "Number of interviews with the head of the SME" (question 5), there is a difference between the two banks (chi-square $=0,000$; Appendix 2F). BIAT loan officers perform a lower number of maintenance ( 1 to 2) (Table 10).

Table 10. Number of interviews with the head of the SME

\begin{tabular}{|c|c|c|c|c|c|c|}
\hline & & 1 & 2 & 3 & 4 & Total \\
\hline \multirow[t]{2}{*}{ BIAT } & Size & 37 & 33 & 9 & 1 & 80 \\
\hline & $\%$ of total ${ }^{\mathrm{a}}$ & 23.1 & 20.6 & 5.6 & 0.6 & 50.0 \\
\hline \multirow[t]{2}{*}{ STB } & Size & 15 & 48 & 13 & 4 & 80 \\
\hline & $\%$ of total ${ }^{\mathrm{a}}$ & 9.4 & 30.0 & 8.1 & 2.5 & 50.0 \\
\hline \multirow[t]{2}{*}{ Total } & Size & 52 & 81 & 22 & 5 & 160 \\
\hline & $\%$ of total ${ }^{\mathrm{a}}$ & 32.5 & 50.6 & 13.8 & 3.1 & 100.0 \\
\hline
\end{tabular}

a. The reasoning is by column, for example: $23.1 \%=37 / 160$.

As meeting time is significant (chi-square $=0.001$; Appendix 2G), STB loan officers spend more time with the head of the SME than those of BIAT (Table 11).

Table 11. The average duration (in hours) of interviews with the head of an SME

\begin{tabular}{|c|c|c|c|c|c|c|c|c|}
\hline & 10 & 15 & 20 & 25 & 30 & 45 & 60 & Total \\
\hline BIAT & 0 & 13 & 13 & 2 & 34 & 9 & 9 & 80 \\
\hline STB & 1 & 8 & 19 & 0 & 16 & 8 & 28 & 80 \\
\hline Total & 1 & 21 & 32 & 2 & 50 & 17 & 37 & 160 \\
\hline
\end{tabular}

The frequency of visits by managers of two banks is not the same (chi-square $=0.000$; Appendix 2H). STB loan officers make more visits to their clients (Table 12). These latter results, although they suggest that STB officials are more motivated by collecting specific information, raise the question of the relevance of the information collected by STB officials about the time spent with their clients (number and length of interviews). We found above (Tables 3 and 4) that STB officials are under less pressure in terms of job performance, and that Tunisian public banks are less efficient than other banks (Banque, 2014, p. 222). This observation calls for further work on the relevance of the information collected by the customer service representatives in terms of the percentage of non-performing loans in the assets of Tunisian banks.

Table 12. Frequency of visits by managers (Number)

\begin{tabular}{|c|c|c|c|c|c|}
\hline & & 1 & 2 & 3 & Total \\
\hline \multirow[t]{2}{*}{ BIAT } & Size & 70 & 10 & 0 & 80 \\
\hline & $\%$ of total $^{\mathrm{a}}$ & 43.8 & 6.3 & 0.0 & 50.0 \\
\hline \multirow[t]{2}{*}{ STB } & Size & 27 & 36 & 17 & 80 \\
\hline & $\%$ of total $^{\mathrm{a}}$ & 16.9 & 22.5 & 10.6 & 50.0 \\
\hline \multirow[t]{2}{*}{ Total } & Size & 97 & 46 & 17 & 160 \\
\hline & $\%$ of total $^{\mathrm{a}}$ & 60.6 & 28.8 & 10.6 & 100.0 \\
\hline
\end{tabular}

a. The reasoning is by column, for example: $43.8 \%=70 / 160$.

The results summarized in Table 13 confirm the one-dimensionality of the "Data collection activity" element.

Table 13. Purification of the construct "Data collection activity"

\begin{tabular}{|c|c|c|c|c|}
\hline \multirow[t]{2}{*}{ Label of the item $i$} & \multirow[t]{2}{*}{ Correlation } & \multirow{2}{*}{$\begin{array}{l}\text { Cronbach's alpha when } \\
\text { the item is deleted }\end{array}$} & \multirow[t]{2}{*}{ Extraction } & \multirow{2}{*}{$\begin{array}{l}\text { Percentage of variance explained: } 63,406 \\
\text { Axis } 1: 63,406\end{array}$} \\
\hline & & & & \\
\hline Interviews & 0.755 & 0.092 & 0.685 & 0.827 \\
\hline Average duration of interviews & 0.705 & 0.340 & 0.787 & 0.887 \\
\hline Frequency of visits & 0.823 & 0.097 & 0.429 & 0.655 \\
\hline $\begin{array}{l}\text { Average length of a credit } \\
\text { application study }\end{array}$ & 0.817 & 0.058 & 0.636 & 0.797 \\
\hline $\mathrm{KMO}=0.761$ & & Global Cronbach's alpha & $=0.623$ & Data collection \\
\hline
\end{tabular}


The KMO index is significant $(0.761)$, with the coefficients of the anti-image matrix greater than 0.5. The percentage of variance explained is in the order of $63 \%$ for a single factor. The scale is well reliable, Cronbach's alpha is 0.623 . The F1 factor includes the four items in question five. The corresponding axis is called "Data Collection". The loan officer's effort depends on his motivation at work, structural factors, and his skills to collect data. To do this we will perform an analysis in principal components for items: Need for success, Participation and self-realization, Behavioral motivation factors, Structural motivation factors, and Data collection activities. The KMO index is significant $(0.761)$, the anti-image matrix coefficient being greater than 0.5 for most items, with the exception of Need for success and self-realization which will be eliminated from the analysis. With a total variance of around $41 \%$ (Table 14) we were able to extract a common factor called "Subjective effort of the loan officer". Concerning the $\mathrm{Hl}-\mathrm{c}$ hypothesis relating to the effort to collect information for the processing of credit files, it is confirmed specifically in state-owned banks, regardless of the relevance of the information collected.

Table 14. Purification of the construct "Subjective effort"

\begin{tabular}{lcccc}
\hline & Label of the item i & Correlation & Extraction & Percentage of variance explained : 40,954 \\
\cline { 4 - 5 } & & & Axis $1: 40,954$ \\
\hline Motivation forms & Need for success & 0,464 & 0,616 \\
& Participation & 0,547 & 0,382 & 0,601 \\
& Self realization & 0,442 & & 0,699 \\
Motivation factors & Organizational & 0,520 & 0,518 & Subjective effort \\
Data collection activity & Data collection & 0,505 & 0,589 & \multicolumn{2}{c}{} \\
\hline
\end{tabular}

\subsection{Level of Participation (Hypothesis H2)}

Regarding the item "You do not issue an opinion but the head of the agency consults you before issuing his opinion" (question 9), most managers of the two banks face this situation, more than 93\% (chi-square $=0.12$; Appendix 2I). This means that agency heads rely on the advice of their loan officers who are in direct contact with SMEs managers. Similarly, $93.7 \%$ of the managers give their opinion on the basis of that of the head of the agency, without difference between the two banks (chi-square $=0.618$; Appendix 2J). However, there is a difference for the item "Give your opinion after talking to the head of the agency" (chi-square $=0.038$; Appendix $2 \mathrm{~K})$. This seems clear, especially on the side of BIAT's loan officers who place greater importance on their supervisors, who have a say in the decision of their evolution. Nevertheless, giving advice independently of one's supervisor is having a lot of importance to the loan officers of the two banks and without difference (chi-square $=0.126$; Appendix 2L).

On the regional management side, and for the two banks (chi-square $=0.064$; Appendix $2 \mathrm{M}$ ), clarifications and suggestions are only requested from the loan officer who knows the file best and who can the best to answer to all suggestions. According to this officer, when the head of the agency participates in the credit committee, he transfers his suggestions to management, that is more than $73 \%(71+46 / 160$ in Table 15$)$ - without difference between the two banks (chi-square $=0.581$; Appendix $2 \mathrm{~N}$ ).

Table 15. The head of the agency participates in the credit committee

\begin{tabular}{|c|c|c|c|c|c|}
\hline & & Neither disagree nor agree & Agree & Absolutely agree & Total \\
\hline \multirow[t]{2}{*}{ BIAT } & Size & 19 & 32 & 29 & 80 \\
\hline & $\%$ of total $^{\mathrm{a}}$ & 11.9 & 20.0 & 18.1 & 50.0 \\
\hline \multirow[t]{2}{*}{ STB } & Size & 24 & 39 & 17 & 80 \\
\hline & $\%$ of total $^{\mathrm{a}}$ & 15.0 & 24.4 & 10.6 & 50.0 \\
\hline \multirow[t]{2}{*}{ Total } & Size & 43 & 71 & 46 & 160 \\
\hline & $\%$ of total $^{\text {a }}$ & 26.9 & 44.4 & 28.8 & 100.0 \\
\hline
\end{tabular}

a. The reasoning is by column, for example: $11.9 \%=19 / 160$.

The analysis of the "Level of participation in decision-making" (Table 16) identifies two main factors: the first recovers $52.586 \%$ of the overall information and the second recovers $15.178 \%$; together they exceed $67 \%$. As the scale of measurement is reliable, the Cronbach's alpha is around 0.882 and the KMO index is significant $(0.828)$. 
This analysis reveals a part called "Direction notice" that includes: Clarification, Management consultation, Assistance of the chief and Assistance with direction to the work of the committee, and a part called "Agency notice" which brings together the other items. Hypothesis $\mathrm{H} 2$ relating to the importance of the involvement of the loan officer in decision-making for the collection of information is verified.

Table 16. Purification of the construct "Agency Direction"

\begin{tabular}{|c|c|c|c|c|c|}
\hline \multirow[t]{2}{*}{ Label of the item $\mathrm{i}$} & \multirow[t]{2}{*}{ Correlation } & \multirow{2}{*}{$\begin{array}{c}\text { Cronbach's alpha } \\
\text { when the item is } \\
\text { deleted }\end{array}$} & \multirow[t]{2}{*}{ Extraction } & \multicolumn{2}{|c|}{$\begin{array}{l}\text { Percentage of the variance explained: } \\
67,764 \\
\end{array}$} \\
\hline & & & & Axis 1: 52,586 & Axis $2: 15,178$ \\
\hline $\begin{array}{l}\text { No opinion issued but consultation by the head } \\
\text { of the agency }\end{array}$ & 0.857 & 0.874 & 0.722 & & 0.834 \\
\hline $\begin{array}{l}\text { An opinion based on the one provided by your } \\
\text { head of agency }\end{array}$ & 0.827 & 0.875 & 0.798 & & 0.888 \\
\hline $\begin{array}{l}\text { An opinion after discussing it with the head of } \\
\text { the agency }\end{array}$ & 0.871 & 0.865 & 0.779 & & 0.826 \\
\hline $\begin{array}{l}\text { An opinion independently of the head of the } \\
\text { agency }\end{array}$ & 0.920 & 0.874 & 0.462 & & 0.567 \\
\hline $\begin{array}{l}\text { Only asks the head of the agency for } \\
\text { clarification }\end{array}$ & 0.914 & 0.859 & 0.646 & 0.587 & \\
\hline Regional management consults you on details & 0.907 & 0.865 & 0.682 & 0.786 & \\
\hline $\begin{array}{l}\text { Head of the agency attends the committee } \\
\text { meeting }\end{array}$ & 0.822 & 0.867 & 0.785 & 0.879 & \\
\hline $\begin{array}{l}\text { An opinion on a decision within the } \\
\text { jurisdiction of the regional management }\end{array}$ & 0.883 & 0.873 & 0.632 & 0.782 & \\
\hline Attend the credit committee's work & 0.922 & 0.865 & 0.594 & 0.667 & \\
\hline Cronbach's alpha all items included & & .882 & & & \\
\hline $\mathrm{KMO}=0.828$ & & & & Direction notice & Agency notice \\
\hline
\end{tabular}

\subsection{Involvement in the Decision-Making Process (Hypothesis H3)}

The analysis of question 8 - "Do you feel close to the hierarchical level empowered to make credit decisions" (Table 17) - reveals that the loan officers of both banks are close to their hierarchical superiors at $85 \%$ $(65+71 / 160$ in Table 17). These conclusions are valid for both banks (chi-square $=0.140$; Appendix 2O), although BIAT officials outperform their STB counterparts; they are $90 \%$ and $80 \%$ respectively $(35+37 / 80$ and $28+36 / 80$ respectively in Table 17 ).

Table 17. Level of proximity to the hierarchical level empowered to make decisions

\begin{tabular}{lllll}
\hline & Neither disagree nor agree & Agree & Absolutly agree & Total \\
\hline STB & 16 & 28 & 36 & 80 \\
BIAT & 8 & 37 & 35 & 80 \\
Total & 24 & 65 & 71 & 160 \\
\hline
\end{tabular}

According to the results of question 10 (Table 18), more than $85 \%$ of the loan officers of the two banks agree that the head of the agency give clear instructions to follow at each stage. They see that the rules and procedures are formulated in advance and they agree. They further assert that the expected results and performance to be achieved are specified by management without defining the working procedures. That said the bank aims to achieve its goal without defining the tools and processes of loan officers. The decision to grant credit is influenced by the skills and personal environment within the agency. They believe that coordination between them and their leaders is effective.

A principal component analysis of these different items (Table 18) shows that direct monitoring and control is felt by the managers of both banks. 
Table 18. Purification of the construct "Monitoring and control"

\begin{tabular}{lllll}
\hline Label of the item i & Correlation & $\begin{array}{l}\text { Cronbach's alpha } \\
\text { when the item is } \\
\text { deleted }\end{array}$ & $\begin{array}{l}\text { Extraction } \\
\end{array}$ & $\begin{array}{l}\text { Percentage of the variance } \\
\text { explained: } 71,001\end{array}$ \\
\hline Instructions of the agency head & 0.877 & 0.865 & 0.742 & 0.862 \\
Rules formulated by the central management & 0.838 & 0.866 & 0.737 & 0.859 \\
Expected results & 0.832 & 0.852 & 0.807 & 0.899 \\
Skills and personal environment within the agency & 0.914 & 0.891 & 0.590 & 0.768 \\
Coordination loan officer- head of the agency & 0.880 & 0.877 & 0.673 & 0.820 \\
\hline \multicolumn{5}{l}{ KMO = 0.864} \\
\hline
\end{tabular}

As a result, it appears that the loan officers of both banks, although they are involved in their agencies in terms of lending decisions, are not well involved in management. This proves that the decision is more centralized in both banks. The hypothesis H3, relating to the relationship of the officer with the hierarchy, is therefore partially validated in terms of involvement in the decision-making process.

\section{Conclusion}

The purpose of this paper is to empirically verify the role of the loan officer in the evolution of the bank-SMEs relationship and his motivation to investigate the credit file, his level of approach to the hierarchy, and his participation in the decision-making process. Analysis of data from a survey of 160 loan officers from two major Tunisian banks (STB and BIAT) shows that the managers of both banks attach importance to factors related to self-esteem, such as salary increase, bonus and recognition from their supervisor, and the need for success, such as the desire to outpace others, the acquisition of new skills, and the adaptation of work to each situation encountered. They emphasize autonomy in the performance of their duties and participation in the decision to grant credit as motivators at work. Direct contacts, in terms of the number of visits to the SME's premises and the average duration of interviews with its manager, are considered important for the acquisition of specific information (soft information) useful for deciding on a credit application. When transferred to headquarters, this information is accompanied by different interpretations of the loan officers, which vary according to their motivations (Nagar, 2002). According to Stein (2002), in banks with a centralized structure, loan officers will be all the less incentive to collect this information as they are little sure of being rewarded for their efforts. For this reason, some banks delegate decision-making rights to these officials and, as a result, establish control and motivational systems that are costly to the enterprise (Jensen \& Meckling, 1992). In fact, the quality of the decision relies on the delegation of the collection and evaluation of specific information to loan officers (Bruns \& Fletcher 2008; Bruns et al., 2008). This implies, according to Uchida et al. (2012, p. 98) that "the relevant relationship in SME lending is the loan officer-entrepreneur relationship, not the bank-entrepreneur relationship". In Tunisian banks (of our sample), decentralization of decision-making powers is the responsibility of the central committees in the STB. To a large extent, these decisions are based on studies carried out by services, created within the directorate-general. In the BIAT, a certain delegation of decision-making powers has been instituted at the regional level. Regional committees hold periodic meetings to decide on credit applications beyond the authority of agencies, group managers, and the area manager. In addition, BIAT officers are closer to their supervisors than those in the STB. Compared to public banks, the decision to evolve in a private bank depends more on the hierarchical superiors, which encourages the loan officers of private banks to be closer to their hierarchical superiors.

The originality of our empirical methodology, described as hypothetic-inductive, lies in the adoption of a multi-method approach in data collection. To this end, the techniques implemented are observation and semi-directive interviews with the loan officers of our sample.

Our results can serve as a starting point for interesting future research, given the ongoing changes in the Tunisian banking system towards a concentration strategy, usually through merger and acquisition (Hakimi et al., 2015). It would be interesting to analyze the evolution of the motivational and evaluation systems of loan officers in a context of bank consolidation, which will provide potential explanations for the effects of concentration on the volume of loans granted to SMEs, and more broadly, on the bank-SMEs relationships. Is there a risk that more SMEs will be push out further from bank credits and loans? It would also be interesting to study the relevance of the information collected by loan officers in the assessment and monitoring of borrowers by examining the methodology for processing bank credit risk, which involves the collection and use of relevant information on borrowers to mitigate information asymmetry (Grunert et al., 2005; Karapetyan \& Stacescu, 2013). 


\section{References}

Adair, P., \& Fhima, F. (2013). Le financement des PME en Tunisie: Dépendance à l'égard des banques et rationnement du crédit. Revue Internationale PME, 26(3-4), 117-138. https://doi.org/10.7202/1024521ar

Adams, J. S. (1963). Toward an understanding of inequity. Journal of Abnormal and Social Psychology, 67(5), 420-436. https://doi.org/10.1037/h0040968

AFC (Arab Financial Consultants) (2012). Note sur les banques cotées. Retrieved from https://fr.slideshare.net/samibou/note-secteur-bancaire-tunisien-09-2012

Agarwal, S., \& Hauswald, R. (2010). Distance and private information in lending. Review of Financial studies, 23(7), 2757-2788. https://doi.org/10.1093/rfs/hhq001

Agostino, M., Silipo, D. B., \& Trivieri, F. (2008). The Effects of Screening and Monitoring on Credit Rationing of SMEs. Economic Notes, 37(2), 155-179. https://doi.org/10.1111/j.1468-0300.2008.00195.x

Alderfer, C. P. (1969). An empirical test of a new theory of human needs. Organizational Behavior and Human Performance, 4(2), 130-175. https://doi.org/10.1016/0030-5073(69)90004-X

Baas, T., \& Schrooten, M. (2006). Relationship Banking and SMEs: A theoretical analysis. Small Business Economics, 27(2), 127-137. https://doi.org/10.1007/s11187-006-0018-7

Banque, M. (2014). La révolution inachevée, Rapport no. 86179-TN. Retrieved from http://documents.worldbank.org/

BCT (Banque Centrale de Tunisie) (2018) Statistiques. Retrieved from https://www.bct.gov.tn/bct/siteprod/stat_index.jsp

Beck, T., Degryse, H., De Haas, R., \& Van Horen, N. (2018). When arm's length is too far. Relationship banking over the business cycle. Journal of Financial Economics, 127(1), 174-196. https://doi.org/10.1016/j.jfineco.2017.11.007

Berger, A. N., Klapper, L. F., \& Udell, G. F. (2001). The ability of banks to lend to informationally opaque small businesses. Journal of Banking and Finance, 25(12), 2127-2167. https://doi.org/10.1016/S0378-4266(01)00189-3

Berger, A. N., \& DeYoung, R. (2001). The effects of geographic expansion on bank efficiency. Journal of Financial Services Resources, 19(2), 163-184. https://doi.org/10.1023/A:1011159405433

Berger, A. N., \& Udell, G. F. (2002). Small business credit availability and relationships lending: The importance of bank organizational structure. Economic Journal, 112(477), $32-53$. https://doi.org/10.1111/1468-0297.00682

Berger, A. N. \& Udell, G. F. (2003). Small business and debt finance, In: Zoltan, Z. I. \& Audretsch, D. B. (eds), Handbook of Entrepreneurship Research, Vol. 1, pp. 299-328, Boston, MA. https://doi.org/10.1007/0-387-24519-7_13

Berger, A. N., \& Udell, G. F. (2006). A more complete conceptual framework for SME finance. Journal of Banking \& Finance, 30(11), 2945-2966. https://doi.org/10.1016/j.jbankfin.2006.05.008

Berger, A. N., Demsetz, R., \& Strahan, P. E. (1999). The consolidation of the financial service industry: Causes, consequences and implication for the future. Journal of Banking and Finance, 23(24), 135-194. https://doi.org/10.1016/S0378-4266(98)00125-3

Berger, A. N., Miller, N. H., Petersen, M. A., Rajan, R. G., \& Stein, J. C. (2005). Does function follow organizational form? Evidence from the lending practices of large and small banks. Journal of Financial Economics, 76(2), 237-261. https://doi.org/10.1016/j.jfineco.2004.06.003

Bruns, V., \& Fletcher, M. (2008), Bank's risk assessment of Swedish SMEs. Venture Capital, 10(2), 171-194. https://doi.org/10.1080/13691060801946089

Bruns, V., Holland, D. V., Shepard, D. A., \& Wiklund, J. (2008). The role of human capital in loan officers' decision policies. Entrepreneurship, Theory and Practice, 32(3), 485-506. https://doi.org/10.1111/j.1540-6520.2008.00237.x

Carter, D. A., Mc Nulty, J. E., \& Verbrugge, J. A. (2004). Do Small Banks have an Advantage in Lending? An Examination of Risk-Adjusted Yields on Business Loans at Large and Small Banks. Journal of Financial Services Research, 25(2-3), 233-252. https://doi.org/10.1023/B:FINA.0000020663.21079.d2 
Cerqueiro, G., Degryse, H., \& Ongena, S. (2011). Rules versus discretion in loan rate setting. Journal of Financial Intermediation, 20(4), 503-529. https://doi.org/10.1016/j.jfi.2010.12.002

Chenhall, R. (2003). Management control systems design within its organizational context: findings from contingency based research and directions for the future. Accounting, Organizations and Society, 28(2-3), 127-168. https://doi.org/10.1016/S0361-3682(01)00027-7

Churchill, G. A. (1979). A Paradigm for developing better measures of marketing constructs. Journal of Marketing Research, 16(1), 64-73. https://doi.org/10.1177/002224377901600110

Cole, R. A., Goldberg, L. G., \& White, L. J. (2004). Cookie-Cutter versus Character: The Micro Structure of Small-Business Lending by Large and Small Banks. Journal of Financial and Quantitative Analysis, 39(2), 227-251. https://doi.org/10.1017/S0022109000003057

Cronbach, L. J. (1951). Coefficient alpha and the internal structure of tests. Psychometrika, 16(3), 297-334. https://doi.org/10.1007/BF02310555

Ennew, C. T., \& Binks, M. R. (1995). The Provision of Finance to Small Businesses: Does the Banking Relationship Constrain Performance. The Journal of Entrepreneurial Finance, 4(1), 57-79. https://digitalcommons.pepperdine.edu/jef/vol4/iss $1 / 3$

Farinha, L., \& Félix, S. (2015). Credit rationing for Portuguese SMEs. Finance Research Letters, 14, 67-177. https://doi.org/10.1016/j.frl.2015.05.001

Fortin, M. F. (2010). Fondements et étapes du processus de recherche (2e éd.). Montréal: Chenelière Éducation.

Grunert, J., Norden, L., \& Weber, M. (2005). The role of non-financial factors in internal credit ratings. Journal of Banking and Finance, 29(2), 509-531. https://doi.org/10.1016/j.jbankfin.2004.05.017

Guille, M. (1994). Savoir bancaire spécifique, marché du crédit et intermédiation financière. Economie Appliquée, 96(4), 49-77.

Hakimi, A., Hamdi, H., \& Djelassi, M. (2015). Testing the concentration-performance relationship in the Tunisian banking sector. East-West Journal of Economics and Business, 18(2), 41-62.

Harhoff, D., \& Körting, T. (1998). Lending relationships in Germany-Empirical evidence from survey data. Journal of Banking and Finance, 22(10), 1317-1353. https://doi.org/10.1016/S0378-4266(98)00061-2

Hauswald, R., \& Marquez, R. (2003). Information Technology and Financial Services Competition. Review of Financial Studies, 16(3), 921-948. https://doi.org/10.1093/rfs/hhg017

Hayes, D. (1977). The contingency theory of management accounting. The Accounting Review, 52(1), 22-39.

Hertzberg, A., Liberti, J. M., \& Paravisini, D. (2010). Information and incentives inside the firm: Evidence from loan officer rotation. Journal of Finance, 65(3), 795-828. https://doi.org/10.1111/j.1540-6261.2010.01553.x

Herzberg, F. (1968). One more time: How do you motivate employees? Harvard Business Review, 46(1), 53-62.

Institut National de la Statistique. Retrieved from http://www.ins.nat.tn/

Jensen, M. C., \& Meckling, W. H. (1992). Specific and general knowledge and organizational structure. In L. Werin, \& H. Wijkander (Eds.), Contract Economics (pp. 251-274). Oxford: Blackwell. http://dx.doi.org/10.2139/ssrn.6658

Kalika, M. (1995). Structures d'entreprise: Réalités, déterminants, performances. Paris, Economica.

Karapetyan, A., \& Stacescu, B. (2013). Information sharing and information acquisition in credit markets. Review of Finance, 18(4), 1583-1615. https://doi.org/10.1093/rof/rft031

Levenson, A. R., \& Willard, K. L. (2000). Do Firms Get the Financing They Want? Measuring Credit Rationing Experienced by Small Business in the U.S. Small Business Economics, 14(2), 83-94. https://doi.org/10.1023/A:1008196002780

Liberti, J. (2004). Initiative, Incentives and Soft Information: How Does Delegation Impact The Role of Bank Relationship Managers? Finance 0404023, University Library of Munich, Germany.

Liberti, J. M., \& Mian A. (2009). Estimating the effect of hierarchies on information use. The Review of Financial Studies, 22(10), 4057-4090. https://doi.org/10.1093/rfs/hhn118

Lipshitz, R., \& Shulimovitz, N. (2007). Intuition and emotion in bank loan officers' credit decisions. Journal of Cognitive Engineering and Decision Making, 1(2), 212-233. https://doi.org/10.1518/155534307X232857 
Locke, E. A. (1968). Toward a theory of task motivation and incentives. Organizational Behavior and Human Performance, 3(2), 157-189. https://doi.org/10.1016/0030-5073(68)90004-4

Maslow, A. H. (1958). Motivation and personality. New York, Harper and Row.

McClelland, D. C. (1961). The Achieving Society. Princeton, Van Nostrand.

McNamara, G., \& Bromiley, P. (1997). Decision making in an organizational setting: Cognitive and organizational influences on risk assessment in commercial lending. Academy of Management Journal, 40(5), 1063-1088. https://doi.org/10.2307/256927

Mester, L., Nakamura, L., \& Renault, M. (2005). Checking accounts and bank monitoring. Federal Reserve Bank of Philadelphia Working Paper, no. 05, p. 42.

Mia, L., \& Chenhall, R. (1994). The usefulness of management accounting systems, functional differentiation and managerial effectiveness. Accounting Organization and Society, 19(1), 1-13. https://doi.org/10.1016/0361-3682(94)90010-8

Milgrom, P., \& Roberts, J. (1992). Economics, Organization and Management. New Jersey: Prentice-Hall International.

Mintzberg, H. (1978). The structuring of organizations: A synthesis of research. Prentice Hall, Englewood.

Mouley, S., \& Hassen, R. (2017). Rapport Annuel sur l'Inclusion Bancaire \& Financière: Tunisie - 2016. Tunis, Instauring an Advocacy Champion for Economy. http://www.iace.tn/wp-content/uploads/2017/03/RapportInclusionfinanciere032017.pdf

Nagar, V. (1999). Organizational Design Choices in Retail Banking. University of Michigan Business School Working Paper, no. 99-007, p. 49.

Nagar, V. (2002). Delegation and incentive compensation. The Accounting Review, 77(2), 379-395. https://doi.org/10.2308/accr.2002.77.2.379

Nakamura, J. (1999). La relation banque - PME. Revue d'Economie Financière, 54, 39-58. https://doi.org/10.3406/ecofi.1999.4064

Petersen, M., \& Rajan, R. (2002). Does Distance Still Matter? The Information Revolution in Small Business Lending. Journal of Finance, 57(6), 2533-2570. https://doi.org/10.1111/1540-6261.00505

Petersen, M. A. (2004). Information: Hard and soft. Northwestern University Working paper, p. 20.

Roberts, M. R. (2015). The role of dynamic renegotiation and asymmetric information in financial contracting. Journal of Financial Economics, 116(1), 61-81. https://doi.org/10.1016/j.jfineco.2014.11.013

Stein, J. C. (2002). Information Production and Capital Allocation: Decentralized Vs. Hierarchical Firms. NBER Working Papers, $n^{\circ} 7705$, p. 49. https://doi:10.3386/w7705

Strahan, E., \& Weston, J. (1996). Small business lending and Bank consolidation is there cause for concern. Current Issues in Economics and Finance, Federal Reserve Bank of New York, 2(3), 1-6. https://doi:10.2139/ssrn.1001240

Trönnberg, C. C., \& Hemlin, S. (2014). Lending decision making in banks: A critical incident study of loan officers. European Management Journal, 32(2), 362-372. https://doi.org/10.1016/j.emj.2013.03.003

Uchida, H., Udell, G. F., \& Yamori, N. (2012). Loan officers and relationship lending to SMEs. Journal of Financial Intermediation, 21(1), 97-122. https://doi.org/10.1016/j.jfi.2011.06.002

Udell, G. (1989). Loan quality, commercial loan review and loan officer contracting. Journal of Banking and Finance, 13(3), 367-382. https://doi.org/10.1016/0378-4266(89)90048-4

Uzzi, B., \& Lancaster, R. (2003). Relational embeddedness and learning: The case of bank loan managers and their clients. Management Science, 49(4), 383-399. https://doi.org/10.1287/mnsc.49.4.383.14427

Vroom, V. H. (1964). Work and motivation. New York: Wiley.

\section{Notes}

Note 1. Strahan and Weston (1996) find, for the period of 1993-1996, that the increase in the size of US banks (measured by total assets) has a negative impact on the volume of loans to SMEs. For banks with less than $\$ 100$ million in assets, the share of loans to SMEs is 0.088 and down to 0.050 and 0.034 for bank assets between $\$ 1$ 
billion and $\$ 5$ billion and assets over $\$ 5$ billion respectively. Similarly, Berger et al. (1999) find, for the year 1997, that US banks with total assets under \$ 100 million present $9 \%$ of their portfolio in the form of credit to SMEs (less than $\$ 1$ million) against only $2 \%$ for those whose total assets exceed \$ 10 billion.

Note 2. Carter et al. (2004) compare the returns on SME loans granted by a sample of 3,263 American banks over the period 1996-1999. They find that small banks (with total assets of less than $\$ 1$ billion) have a return equal to $11.10 \%$ compared to $9.46 \%$ for large banks.

Note 3. Mintzberg (1978) states that the strategic summit is linked to the operating center by the hierarchical line. This line ranges from the ranks below the strategic top up to the top level coaching that has power over the operators.

Note 4. At the end of year 2018, The Tunisian banking system was composed by 42 banking and financial institutions, including 23 resident banks, 8 leasing companies, 2 factoring companies, 2 investment banks, and 7 non-resident banks (BCT, 2018, p. 127).

Note 5. A construct is constructed from many indicators that form together a scale for measuring the intensity of a well-defined phenomenon. Each of these indicators is defined as items (Churchill, 1979).

Note 6. According to Mia and Chenhall (1994) and Chenhall (2003), analyzing a single function or a single activity within a company seems to be sufficient to apprehend the coherence and the complementarity of the organizational structure's components.

Note 7. The anti-image matrix is an additional observation of the factorizable character of data which was not included in this paper as well as other additional statistical tests. But, they can be available upon request.

\section{Appendix 1. Questionnaire}

1. What is the name of your bank? The location of your agency?

2. The characteristics of the loan officer (gender, age, training, ... etc.)

3. What kind of contact do you prefer with the manager of a small business for which you are responsible? Please rank these contact modes from 1: "most important" to 5: "least important":

\begin{tabular}{lllll}
\hline Meeting & Phone & Email & Fax & Mail \\
\hline
\end{tabular}

4. Please check the level of importance you place on each SME data collection activity described below?

\begin{tabular}{|c|c|c|c|c|c|}
\hline & $\begin{array}{l}\text { Not at all } \\
\text { important }\end{array}$ & $\begin{array}{l}\text { Not } \\
\text { important }\end{array}$ & $\begin{array}{l}\text { Slightly } \\
\text { important }\end{array}$ & Important & $\begin{array}{c}\text { Very } \\
\text { important }\end{array}$ \\
\hline \multicolumn{6}{|l|}{ Interviews (in numbers) with the head of an SME requesting a credit } \\
\hline \multicolumn{6}{|l|}{$\begin{array}{l}\text { The average duration (in hours) of interviews with the head of an SME } \\
\text { requesting a credit }\end{array}$} \\
\hline \multicolumn{6}{|l|}{$\begin{array}{l}\text { The frequency of visits (in numbers) to the premises of an SME } \\
\text { requesting a credit }\end{array}$} \\
\hline $\begin{array}{l}\text { The average length of time (hours, day or month) to complete a credit } \\
\text { application study }\end{array}$ & & & & & \\
\hline
\end{tabular}

5. Please indicate the number or duration of data collection activities?

Number or duration (hours, days or months)

Interviews (in numbers) with the head of an SME requesting a credit

The average duration (in hours) of interviews with the head of an SME requesting a credit

The frequency of visits (in numbers) to the premises of an SME requesting a credit

The average length of time (hours, days or months) to complete a credit application study 
6. Please check the following forms of work motivation that encourage you to increase your commitment to work?

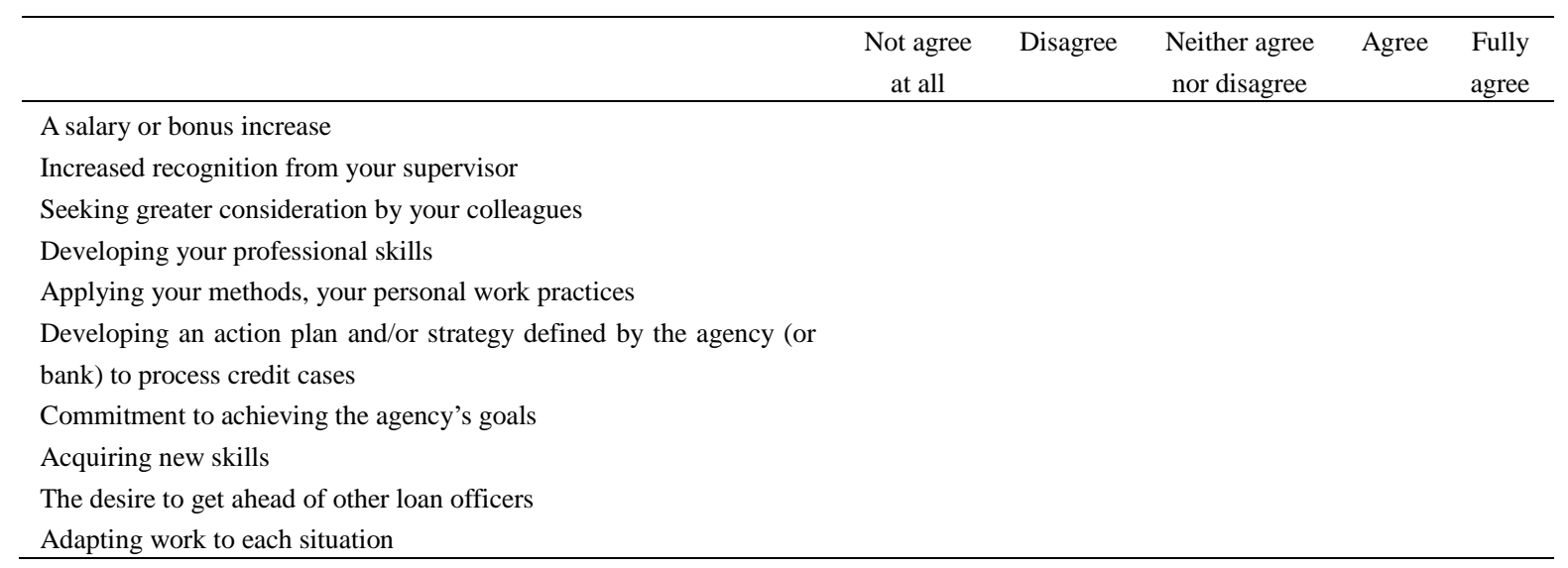

7. Do you consider these aspects of your job to be motivating factors?

\begin{tabular}{lccc}
\hline & $\begin{array}{c}\text { Not agree } \\
\text { at all }\end{array}$ & $\begin{array}{c}\text { Disagree } \\
\text { Neither agree } \\
\text { nor disagree }\end{array}$ & $\begin{array}{c}\text { Agree } \\
\text { Fully } \\
\text { agree }\end{array}$ \\
\hline $\begin{array}{l}\text { The diversity of tasks } \\
\text { The autonomy in the performance of your duties }\end{array}$ & & \\
The initiative in the decision-making \\
The use of the knowledge gained from the processing of cases \\
The participation in the decision to grant credit
\end{tabular}

8. Do you feel that you are close to the hierarchical level empowered to make credit decisions?

\begin{tabular}{|c|c|c|c|c|}
\hline Not agree at all & Disagree & Neither agree nor disagree & Agree & Fully agree \\
\hline
\end{tabular}

9. To what extent, does each of these actions describe the level of your participation in decision-making?

\begin{tabular}{|c|c|c|c|c|c|}
\hline & $\begin{array}{c}\text { Not agree } \\
\text { at all }\end{array}$ & Disagree & $\begin{array}{c}\text { Neither agree } \\
\text { nor disagree }\end{array}$ & Agree & $\begin{array}{l}\text { Fully } \\
\text { agree }\end{array}$ \\
\hline \multicolumn{6}{|l|}{ You do not issue an opinion but the head of the agency consults you } \\
\hline \multicolumn{6}{|l|}{ You give an opinion based on the one provided by your head of agency } \\
\hline \multirow{2}{*}{\multicolumn{6}{|c|}{$\begin{array}{l}\text { You issue an opinion regarding the decision to grant the credit after } \\
\text { discussing it with the head of the agency }\end{array}$}} \\
\hline & & & & & \\
\hline \multicolumn{6}{|l|}{ You issue an opinion independently of the head of the agency } \\
\hline \multirow{2}{*}{\multicolumn{6}{|c|}{$\begin{array}{l}\text { The regional management only asks the head of the agency for } \\
\text { clarification }\end{array}$}} \\
\hline & & & & & \\
\hline \multirow{2}{*}{\multicolumn{6}{|c|}{$\begin{array}{l}\text { The regional management consults you on details of the study } \\
\text { presented by the agency }\end{array}$}} \\
\hline & & & & & \\
\hline \multirow{2}{*}{\multicolumn{6}{|c|}{$\begin{array}{l}\text { The head of the agency attends the committee meeting and tells about } \\
\text { your suggestions }\end{array}$}} \\
\hline & & & & & \\
\hline \multirow{2}{*}{\multicolumn{6}{|c|}{$\begin{array}{l}\text { You give an opinion on a decision within the jurisdiction of the } \\
\text { regional management }\end{array}$}} \\
\hline & & & & & \\
\hline You attend the credit committee's work to formulate your opinion & & & & & \\
\hline
\end{tabular}


10. What do you think of the following statements about the following management activities provided by your bank's management?

\begin{tabular}{|c|c|c|c|c|c|}
\hline & $\begin{array}{c}\text { Not agree } \\
\text { at all }\end{array}$ & Disagree & $\begin{array}{c}\text { Neither agree } \\
\text { nor disagree }\end{array}$ & Agree & Fully agree \\
\hline \multicolumn{6}{|l|}{$\begin{array}{l}\text { The agency head's instructions are defined at each stage of the } \\
\text { work, with no standards to follow }\end{array}$} \\
\hline \multicolumn{6}{|l|}{$\begin{array}{l}\text { The rules, processes are formulated in advance by the central } \\
\text { management for the exercise of your activity }\end{array}$} \\
\hline \multicolumn{6}{|l|}{$\begin{array}{l}\text { Expected results and performance to be achieved are specified by } \\
\text { management without defining work processes }\end{array}$} \\
\hline \multicolumn{6}{|l|}{$\begin{array}{l}\text { Skills and personal environment within the agency influence the } \\
\text { decision to grant credit }\end{array}$} \\
\hline $\begin{array}{l}\text { The coordination between you and the head of the agency is } \\
\text { effective (achieved) }\end{array}$ & & & & & \\
\hline
\end{tabular}

\section{Appendix 2. Chi-square tests}

\begin{tabular}{lccc}
\hline A & Value & Degrees of freedom & Asymptotic value (bilateral) \\
\hline Pearson chi-square & $8.512^{\text {a }}$ & 4 & 0.075 \\
Likelihood ratio & 8.743 & 4 & 0.068 \\
Linear-by-linear association & 0.053 & 1 & 0.818 \\
Valid observations number & 160 & & \\
\hline
\end{tabular}

a. 0 cells $(0.0 \%)$ have a theoretical size of less than 5 . The minimum theoretical size is 9.50 .

\begin{tabular}{lccc}
\hline B & Value & Degrees of freedom & Asymptotic value (bilateral) \\
\hline Pearson chi-square & $6.759^{\mathrm{a}}$ & 2 & 0.034 \\
Likelihood ratio & 8.321 & 2 & 0.016 \\
Linear-by-linear association & 0.196 & 1 & 0.658 \\
Valid observations number & 160 & & \\
\hline
\end{tabular}

a. 2 cells $(33.3 \%)$ have a theoretical size of less than 5 . The minimum theoretical size is 2.00 .

\begin{tabular}{lccccc}
\hline C & Value & $\begin{array}{c}\text { Degrees of } \\
\text { freedom }\end{array}$ & $\begin{array}{c}\text { Asymptotic } \\
\text { value (bilateral) }\end{array}$ & $\begin{array}{c}\text { Exact significance } \\
\text { (bilateral) }\end{array}$ & $\begin{array}{c}\text { Exact significance } \\
\text { (unilateral) }\end{array}$ \\
\hline Pearson chi-square & $4.025^{\mathrm{a}}$ & 1 & 0.045 & & \\
Correction pour la continuité & 3.382 & 1 & 0.066 & & 0.033 \\
Likelihood ratio & 4.050 & 1 & 0.044 & & \\
Test exact de Fisher & & & & & \\
Linear-by-linear association & 4.000 & 1 & 0.046 & & \\
Valid observations number & 160 & & & & \\
\hline
\end{tabular}

${ }^{\mathrm{a}} 0$ cells $(0.0 \%)$ have a theoretical size of less than 5 . The minimum theoretical size is 27.00 .

${ }^{\mathrm{b}}$ Calculated only for an array $2 \times 2$.

\begin{tabular}{llll}
\hline $\mathrm{D}$ & Value & Degrees of freedom & Asymptotic value (bilateral) \\
\hline Pearson chi-square & $0.678^{\mathrm{a}}$ & 2 & 0.713 \\
Likelihood ratio & 0.678 & 2 & 0.712 \\
Linear-by-linear association & 0.444 & 1 & 0.505 \\
Valid observations number & 160 & & \\
\hline
\end{tabular}

${ }^{\mathrm{a}} 2$ cells $(33.3 \%)$ have a theoretical size of less than 5 . The minimum theoretical size is 4.00 .

\begin{tabular}{lc}
\hline E & Chi-square test \\
\hline Diversity of tasks & 0.344 \\
Autonomy in the performance of duties & 0.869 \\
Initiative in the decision-making & 0.245 \\
Use of the knowledge gained from the processing of cases & 0.333 \\
Participation in the grant credit decision & 0.440 \\
\hline
\end{tabular}




\begin{tabular}{lccc}
\hline $\mathrm{F}$ & Value & Degrees of freedom & Asymptotic value (bilateral) \\
\hline Pearson chi-square & $57.395^{\mathrm{a}}$ & 2 & 0.000 \\
Likelihood ratio & 63.946 & 2 & 0.000 \\
Linear-by-linear association & 55.525 & 1 & 0.000 \\
Valid observations number & 160 & & \\
\hline
\end{tabular}

a. 0 cells $(0.0 \%)$ have a theoretical size of less than 5 . The minimum theoretical size is 23.50 .

\begin{tabular}{lccc}
\hline $\mathrm{G}$ & Value & Degrees of freedom & Asymptotic value (bilateral) \\
\hline Pearson chi-square & $21.611^{\mathrm{a}}$ & 6 & 0.001 \\
Likelihood ratio & 23.418 & 6 & 0.001 \\
Linear-by-linear association & 7.344 & 1 & 0.007 \\
Valid observations number & 160 & & \\
\hline
\end{tabular}

${ }^{\mathrm{a}} 4$ cells $(28.6 \%)$ have a theoretical size of less than 5 . The minimum theoretical size is 0.50 .

\begin{tabular}{lccc}
\hline $\mathrm{H}$ & Value & Degrees of freedom & Asymptotic value (bilateral) \\
\hline Pearson chi-square & $50.758^{\text {a }}$ & 2 & 0.000 \\
Likelihood ratio & 58.908 & 2 & 0.000 \\
Linear-by-linear association & 48.345 & 1 & 0.000 \\
Valid observations number & 160 & & \\
\hline
\end{tabular}

a. 0 cells $(0.0 \%)$ have a theoretical size of less than 5 . The minimum theoretical size is de 8.50 .

\begin{tabular}{lccc}
\hline I & Value & Degrees of freedom & Asymptotic value (bilateral) \\
\hline Pearson chi-square & $7.303^{\text {a }}$ & 4 & 0.121 \\
Likelihood ratio & 8.182 & 4 & 0.085 \\
Linear-by-linear association & 7.153 & 1 & 0.007 \\
Valid observations number & 160 & & \\
\hline
\end{tabular}

a. 6 cells $(60.0 \%)$ have a theoretical size of less than 5. The minimum theoretical size is 0.50 .

\begin{tabular}{lccc}
\hline $\mathrm{J}$ & Value & Degrees of freedom & Asymptotic value (bilateral) \\
\hline Pearson chi-square & $1.784^{\mathrm{a}}$ & 3 & 0.618 \\
Likelihood ratio & 1.844 & 3 & 0.605 \\
Linear-by-linear association & 0.838 & 1 & 0.360 \\
Valid observations number & 160 & & \\
\hline
\end{tabular}

${ }^{a} 4$ cells $(50.0 \%)$ have a theoretical size of less than 5 . The minimum theoretical size is 2.00 .

\begin{tabular}{lccc}
\hline $\mathrm{K}$ & Value & Degrees of freedom & Asymptotic value (bilateral) \\
\hline Pearson chi-square & $10.172^{\text {a }}$ & 4 & 0.038 \\
Likelihood ratio & 11.572 & 4 & 0.021 \\
Linear-by-linear association & 7.728 & 1 & 0.005 \\
Valid observations number & 160 & & \\
\hline
\end{tabular}

${ }^{\mathrm{a}} 4$ cells $(40.0 \%)$ have a theoretical size of less than 5 . The minimum theoretical size is 0.50 .

\begin{tabular}{lccc}
\hline L & Value & Degrees of freedom & Asymptotic value (bilateral) \\
\hline Pearson chi-square & $7.189^{\mathrm{a}}$ & 4 & 0.126 \\
Likelihood ratio & 8.109 & 4 & 0.088 \\
Linear-by-linear association & 6.303 & 1 & 0.012 \\
Valid observations number & 160 & & \\
\hline
\end{tabular}

${ }^{\text {a }} 4$ cells $(40.0 \%)$ have a theoretical size of less than 5 . The minimum theoretical size is 1.00 .

\begin{tabular}{llll}
\hline $\mathrm{M}$ & Value & Degrees of freedom & Asymptotic value (bilateral) \\
\hline Pearson chi-square & $8.867^{\mathrm{a}}$ & 4 & 0.064 \\
Likelihood ratio & 9.046 & 4 & 0.060 \\
Linear-by-linear association & 4.508 & 1 & 0.034 \\
Valid observations number & 160 & & \\
\hline
\end{tabular}

a 2 cells (20.0\%) have a theoretical size of less than 5. The minimum theoretical size is 2.00 . 


\begin{tabular}{llll}
\hline $\mathrm{N}$ & Value & Degrees of freedom & Asymptotic value (bilateral) \\
\hline Pearson chi-square & $3.781^{\mathrm{a}}$ & 5 & 0.581 \\
Likelihood ratio & 4.222 & 5 & 0.518 \\
Linear-by-linear association & 2.422 & 1 & 0.120 \\
Valid observations number & 160 & & \\
\hline
\end{tabular}

a 4 cells (33.3\%) have a theoretical size of less than 5. The minimum theoretical size is 0.50 .

\begin{tabular}{llll}
\hline $\mathrm{O}$ & Value & Degrees of freedom & Asymptotic value (bilateral) \\
\hline Pearson chi-square & $3.927^{\mathrm{a}}$ & 2 & 0.140 \\
Likelihood ratio & 3.983 & 2 & 0.137 \\
Linear-by-linear association & 0.600 & 1 & 0.439 \\
Valid observations number & 160 & & \\
\hline
\end{tabular}

${ }^{\text {a }} 0$ cells $(0.0 \%)$ have a theoretical size of less than 5 . The minimum theoretical size is 12.00 .

\section{Copyrights}

Copyright for this article is retained by the author(s), with first publication rights granted to the journal.

This is an open-access article distributed under the terms and conditions of the Creative Commons Attribution license (http://creativecommons.org/licenses/by/4.0/). 